Актуальні проблеми розвитку економіки регіону. Вип 17. Т.1

5. "The impact of the COVID-19 pandemic on local finances." U-Lead with Europe, decentralization.gov.ua/uploads/library/file/716/ULEAD_COVID19_Report_29.04.2021_.pdf. Accessed 18 June 2020

6. State Tax Service of Ukraine, tax.gov.ua. Accessed 18 June 2020

7. State Statistics Service of Ukraine, www.ukrstat.gov.ua. Accessed 15 March 2020

8. Dmitrovska, V.S., and I.V.Kokhan. "Local budget revenues in the context of the COVID-19 pandemic. The actual problems of regional economy development, vol.1, no. 16, 2020, pp. 180-190

9. Mulesa, E.V. "Analysis of the filling of local budgets under the influence of the Covid-19 pandemic." Current issues of economics, accounting, finance and personnel management: Zbirnyk materialiv III Mizhnar. nauk.-prakt. konf. Uzhhorod,Uzhhorod National University Publishing House "Hoverla", 2021, pp. $17-19$

10. Resolution of the Cabinet of Ministers of March 29, 2020 № 253 “On Amendments to the Resolution of the Cabinet of Ministers of Ukraine of May 15, 2019 № 555”, zakon.rada.gov.ua/laws/show/253-2020\%D0\%BF\#Text. Accessed Accessed 18 June 2020

11. Storonyanska, I.Z., and L.Ya. Benovska. "Economy of the regions of Ukraine under the influence of the challenges of the COVID-19 pandemic.” Rehionalna ekonomika, no.2, 2020, pp.5-16.

УДК 332.122:332.021

doi: 10.15330/apred.1.17.153-162

\title{
СМАРТ-СПЕЦІАЛІЗАЦІЯ У ПОСТУЛАТАХ ЕКОНОМІЧНИХ ШКІЛ: ТЕОРЕТИЧНИЙ ДИСКУРС
}

\author{
ДУ «Інститут регіональних досліджень імені М.I. \\ Долішнього НАН України», \\ Національна академія наук України, \\ Відділ регіональної фінансової політики, \\ вул. Козельницька, 4, м. Львів, \\ 79026,Україна, \\ тел.: 0503716779, \\ e-mail: gvoznyak@gmail.com, \\ ORCID : 0000-0003-2001-0516
}

\begin{abstract}
Анотація. В статті проведено огляд сучасних теорій економічного розвитку територій, доцільність врахування яких дасть змогу скоротити розрив між практичною спрямованістю смарт-спеціалізації та іiї теоретично обгрунтованою концепцією. Метою статті є дослідження еволюції теорій у постулатах економічних шкіл, які формують теоретичний базис смартспеціалізації регіонів. Застосування методів логічного узагальнення, аналізу та історичного підходу дало змогу стверджувати, що теоретичне підгрунтя смарт-спеціалізації формують ідеї теорії ендогенного зростання, теоретичні постулати нерівномірного розвитку, окремі позиції теорії креативного класу, інформаційного суспільства, низка положень теорії колективних дій тощо. 3'ясовано, що формування теоретичного концепту смарт-спеціалізації регіонів на сучасному етапі пов'язано із актуалізацією теорії ендогенного зростання, ключова ідея якої базується на орієнтації на внутрішні чинники та механізми технологічного прогресу, які в сукупності здатні забезпечити саморозвиток і самовідтворення цілісних соціально-економічних систем. Збалансоване поєднання державного втручання, протекціонізму та стратегічних інвестицій - визначальні детермінанти економічного поступу прихильників теорії «економічного націоналізму», яка переконливо доводить, що тільки завдяки індустріалізації можна досягнути добробуту. Аргументовано, що 3 кожним роком традиційні чинники
\end{abstract}

\footnotetext{
* Дослідження виконано в рамках науково-дослідної теми «Методологічні засади smart-спеціалізації регіонів України» (номер державної реєстрації 0119U001869)
} 
економічного зростання втрачають свою вагу, натомість більшого значення набуває креативний клас, а відкритість і спільне використання стають новітніми принципами розвитку соціальноекономічних систем. Спільним вираженням аналізованих концепцій $є$ розбудова взаємозв'язків між стейкхолдерами, розбудова і посилення багатостороннього партнерства, комунікації із зовнішніми мережами, формування і просування унікальності регіону. Саме такі домінанти, синергія яких гарантуватиме підприємницьке відкриття та конкурентну перевагу регіону набувають особливої актуальності в існуючих умовах. Проведене дослідження вказує на необхідність застосування ключових положень даних теоретичних концепцій при обгрунтуванні теоретико-методологічного ядра смарт-спеціалізації.

Ключові слова: смарт-спеціалізація, регіон, економічне зростання, збалансоване зростання, новітні технології, технологічні зміни

\title{
SMART SPECIALIZATION IN THE POSTULATES OF ECONOMIC SCHOOLS: THEORETICAL DISCOURSE
}

\author{
SI "Institute of Regional Research named after M. I. \\ Dolishniy of the NAS of Ukraine”, \\ Department of Regional Financial Policy, \\ Kozelnytska, 4, Lviv, \\ 79026, Ukraine, \\ тел.: 0503716779, \\ e-mail: gvoznyak@gmail.com, \\ ORCID : 0000-0003-2001-0516
}

\begin{abstract}
The article reviews modern theories of economic development of territories, the expediency of which will allow to reduce the gap between the practical orientation of smart specialization and its theoretically sound concept. The aim of the article is to study the evolution of theories in the postulates of economic schools, which form the theoretical basis of smart specialization of regions. The application of methods of logical generalization, analysis and historical approach allowed to assert that the theoretical basis of smart specialization is formed by ideas of endogenous growth theory, theoretical postulates of uneven development, separate positions of creative class theory, information society, a number of provisions of collective action theory. It is found that the formation of the theoretical concept of smart specialization of regions at the present stage is associated with the actualization of the theory of endogenous growth, the key idea of which is based on internal factors and mechanisms of technological progress, which together can ensure self-development and self-reproduction systems. A balanced combination of government intervention, protectionism and strategic investment are the determining determinants of the economic progress of the proponents of the theory of "economic nationalism", which convincingly proves that only through industrialization can prosperity be achieved. It is argued that every year the traditional factors of economic growth lose their weight, while the creative class becomes more important, and openness and sharing become the latest principles of socio-economic systems. The common expression of the analyzed concepts is the development of relationships between stakeholders, the development and strengthening of multilateral partnerships, communication with external networks, the formation and promotion of the uniqueness of the region. Such dominants, the synergy of which will guarantee entrepreneurial opening and competitive advantage of the region, become especially relevant in the current conditions. The study indicates the need to apply the key provisions of these theoretical concepts in substantiating the theoretical and methodological core of smart specialization.
\end{abstract}

Key words: smart specialization, region, economic growth, balanced growth, latest technologies, technological changes

Вступ. Стратегування соціально-економічного розвитку регіонів $є$ ключовим механізмом реалізації державної регіональної політики. В Україні у 2021 - 2027 рр. стратегічними документами передбачена реалізація нової регіональної політики, суть 
якої визначає перехід від територіально-нейтральної до територіально спрямованої політики розвитку територій на основі стимулювання використання їх власного потенціалу. Такі новації відповідають принципам європейської моделі регіонального розвитку та опираються на смарт-спеціалізацію як методологічну основу стратегування регіонального розвитку. Вважається, що концепція смарт-спеціалізації завдяки ефективному використанню публічних інвестицій, нарощенню інноваційного потенціалу та концентруючи обмежені фінансові і людські ресурси на потенційно конкурентоспроможних сферах, покликана сприяти економічному зростанню регіонів.

Разом 3 тим, концепція смарт-спеціалізації - це приклад «політики, що йде попереду теорії». А тому в цьому сенсі потрібно погодитись із тезою ідеологів концепту [1]: «... хоча смарт-спеціалізація, здається, вже стала політичним хітом, і розробники політики демонструють деякі шалені зобов'язання 3 приводу смартспеціалізації, концепція не є строго обгрунтованою, зокрема як академічна концепція... Тому існує розрив між практичною політикою та теорією».

Постановка завдання. Різні аспекти окресленої проблематики є предметом наукових пошуків як вітчизняних, так і зарубіжних представників економічної науки. Так, ідеологічні основи концепції смарт-спеціалізації сформовані групою експертів за сприяння Директорату з питань технологій та інновацій Свропейської комісії на чолі 3 Д. Форейем, П. Девідом та Б. Холлом, які запропонували концепт, що спричинив значний вплив на політичну аудиторію в Європі, а потім і далеко за ії межами [1]. Можливі напрями впровадження смарт-спеціалізації та особливості іiі адаптації до вітчизняної практики обговорюються в напрацюваннях Бєлявцева В. та Хрипунова Д.[2]. Особливості застосування концепції смарт-спеціалізації в контексті забезпечення сталого розвитку старих промислових вугледобувних регіонів $є$ предметом наукових пошуків О. Амоші, О. Ляха, М. Солдака, Д. Череватського [3]. Доцільність залучення кластерів до реалізації стратегії розумної спеціалізації аргументована в дослідженні [4]. Обгрунтування теоретико-методологічних засад формування моделі смарт-спеціалізації регіонів з акцентуванням на дуальному характері ії функціонування здійснено в праці [5]. Проблеми зміцнення конкурентоспроможності регіону, в залежності від ефективної діяльності місцевого самоврядування та територіальних громад, на основі смартспеціалізації активно дискуються в дослідженні [6] і ін. Попри значний доробок та наукову полеміку щодо доцільності адаптації європейської практики смартспеціалізації в Україні, ідейний арсенал теоретичних концепцій, які розкривають сутність смарт-спеціалізації, як нам видається, не такий він вже і широкий, а тому доцільно зупинитися на тих, які найбільше відповідають сучасним завданням дослідження політики розвитку регіонів, висновки за якими можуть мати теоретичну і практичну значущість.

Метою статті є дослідження еволюції теорій у постулатах економічних шкіл, які формують теоретичний базис смарт-спеціалізації регіонів.

Результати. Ведучи мову про сучасні теорії економічного зростання регіонів на засадах зміцнення конкурентоспроможності їх економіки, доцільно звернути увагу на запропонований П. Ромером [7] підхід до побудови моделей економічного зростання, який базується на ендогенних змінах в економіці. В рамках запропонованої теорії технологічні досягнення $є$ не просто наслідком екзогенних джерел, а створюються за рахунок цілеспрямованої діяльності на ринку. Ключова ідея концепції ендогенного зростання - це орієнтація на внутрішні чинники та механізми технологічного прогресу, які в сукупності здатні забезпечити саморозвиток і самовідтворення цілісних соціальноекономічних систем. Модель економіки представляють людський капітал та нагромаджені знання, які здатні матеріалізуватися в нові технології. Основними факторами ендогенного зростання за П. Ромером є технологічні зміни, які стають 
можливими завдяки цілеспрямованій діяльності людей, що реагують належним чином на постійно змінні ринкові умови[7]. У своїй теорії вчений зумів довести як ідеї нових товарів та послуг, створених за допомогою нових технологій, можуть призвести до економічного зростання і які саме заходи потрібно реалізувати аби цей процес був успішним. Автор обгрунтував домінуючу роль факторів довгострокового економічного зростання (людський капітал, технологічні зміни і знання) на противагу механізмам монетарної чи фіскальної політики, спрямованих на збалансування циклічних коливань. Інакше кажучи, економіка, яка опирається на людський капітал та науку приречена на стійке зростання в довготривалому періоді. Ідеї мають вартість [8].

Засадничими положеннями, які формують модель ендогенного зростання за П. Ромером є [9]:

- найважливішим чинником економічного зростання $є$ технологічні зміни, які дозволяють використовувати різноманітні сполучення наявних у суспільства чинників виробництва;

- технологічні зміни відбуваються завдяки діяльності людей, які реагують на ринкові стимули;

- виробничі технології відрізняються від інших економічних товарів, але створення нових технологій еквівалентно постійним витратам виробництва, а їх подальше використання не потребує від виробника додаткових витрат.

Потрібно наголосити, що теоретичні висновки Ромера лягли в основу досліджень ендогенного зростання та спровокували низку активних емпіричних пошуків, які, в тому числі, можна долучати до обгрунтування смарт-спеціалізації.

Аналізуючи концепти, які можуть слугувати підгрунтям смарт-спеціалізації, не можна оминути увагою теоретичні постулати теорії нерівномірного розвитку, які послідовно відстоює відомий норвезький економіст, критик неолібералізму та палкий прихильник «економічного націоналізму» Е. Райнерт. У своїй знаменитій праці (яка стала бестселером) «Як багаті країни стали багатими ... і чому бідні країни лишаються бідними» [10] автор довів, що багаті країни стали багатими не завдяки вільній торгівлі, а збалансованому поєднанню державного втручання, протекціонізму та стратегічних інвестицій. На думку автора, «в центрі економіки знаходиться не торгівля, а виробництво та інновації (а для інновацій потрібен: синергетичний ефект, системна підтримка, співпраця університету, промисловості і держави). Просто країнам, у яких виробництво налагоджене, важливо продавати вироблені товари на зовнішній ринок, i торгівля опиняється в центрі уваги, буцімто вона $\epsilon$ причиною, а не наслідком успіху» [10].

Наскрізною ідеєю вчень цього дослідника є твердження про те, що основою економіки успішної країни $\epsilon$ національна промисловість i тільки завдяки індустріалізації можна досягнути добробуту (не враховуючи країн-експортерів нафти). Багаті країни змогли досягнути успіху тільки тому, що їхні уряди впродовж певного часу підтримували окремі галузі промисловості та послуг.

Підтримка промисловості $\epsilon$ архі важливою і з позиції розвитку бідних країн. Справа в тому, що наявність в регіоні високо розвинутих галузей буде «підтягувати» низько розвинуті. Е. Райнерт стверджує, що: «... перукарі зможуть багато заробляти тільки там, де $\epsilon$ розвинена промисловість. А регіональне елітне сільське господарство (як-от сир-пармезан та пармська шинка) може виникнути там, де $\epsilon$ такі високотехнологічні індустрії, як-от виробництво Mitsubishi. Тому краще мати погану промисловість, ніж жодної» [10].

Інший важливий висновок, що представляє науковий інтерес в контексті нашого дослідження - успішні західні країни розвивалися не завдяки спеціалізації, а навпаки диверсифікації з пріоритетом оброблювальної промисловості (чим більше у місті 
професій, тим воно багатше). Країни багатіли завдяки емуляції - наслідуванню, копіюванню й перевершенню добрих практик інших країн. Відбувалася битва за індустрії, що приносять найбільші прибутки, часом, варто визнати, не надто чесна. До прикладу, Англія викупила всю іспанську вовну, щоб завадити розвитку сектору обробки бавовни в Іспанії. Сировину, якої було забагато, Англія спалила. Сучасніший приклад: так зробили США, коли замість спеціалізуватися на сільському господарстві, що було чільною індустрією століття тому, почали стимулювати космічні технології СРСР. Американці послуговувались настановою робити не так, як радять англійці, а так, як англійці самі роблять. Китай застосував цей принцип до Америки [10].

Висновки з досліджень Е. Райтнера, які можуть бути корисними в контексті нашого наукового пошуку: економічне процвітання країни залежить від державної політики, яка повинна бути виваженою і збалансованою - в разі потреби держава вживає захисні заходи розвитку зародкових індустрій, в протилежному випадку відкривається до світового ринку. На практиці ніколи не спрацьовує в повному обсязі чи то планова чи нерегульована економіка.

Однією 3 новітніх теорій, що пропонує вирішення проблеми регіонального розвитку, окремі позиції якої можуть слугувати обгрунтуванням концепту смартспеціалізації $є$ теорія креативного класу, запропонована американсько-канадським економістом і соціологом Р. Флоридом на початку XXI століття. У своїй книзі «Ното creatives. Як новий клас завойовує світ» автор запропонував теорію розвитку міст, в якій ввів поняття «креативності» - створення важливих форм, які $є$ найціннішим продуктом в економіці [11]. За Флорідою, «Розвиток сучасного міста не можливий без працівника креативного сектора, який є уособленням духу і часу сучасного міста. Саме креативний клас здатний спричинити докорінні зміни у способах праці, цінностях, бажаннях ...». Креативність $є$ рушійною силою економічного розвитку». Майбутнє належить креативному класу [12].

В своєму дослідженні автор зумів довести, що технології, компанії, венчурний капітал переміщується дуди, де $є$ концентрація талановитих та креативних людей, які надають перевагу місцям, що вирізняються різноманіттям, толерантністю і відкритістю до нових ідей. Цю гіпотезу було протестовано за допомогою низки індексів, серед яких коефіцієнт креативності як функція від трьох факторів: технології, талант, толерантність. Було емпірично доведено істотну взаємодію між показниками технологій i креативним класом. Толерантність у цій теорії розглядається як відкритість до різноманіття. Найбільш ефективно нові ідеї народжуються в місцях, де толерують різні когнітивні стилі, що по'вязані з демографічним різноманіттям. У своєму дослідження Р.Флорида підтвердив сильну кореляцію між тим, наскільки місця, що $є$ толерантними до іммігрантів, митців, геїв, богеми сприяють їх інтеграції, впливають на високе економічне зростання регіону [12].

Основні постулати економічного зростання регіонів відповідно до теорії креативного класу зводяться до такого:

- економічне зростання залежить від здатності креативних людей продукувати нові технології;

- концентрація креативних людей відбувається у місцях відкритих для нового досвіду, де панує толерантність, різноманіття;

- талановиті, креативні люди як фінансові потоки здатні переливатись у місця, які їх приваблюють;

- технології, компанії, венчурний капітал переміщується туди, де є концентрації талановитих та креативних людей [12].

Зважаючи на ту обставину, що креативний клас формує економіку, в якій традиційні чинники з кожним роком втрачають свою вагу, а все більшого значення 
набувають творчі, інноваційні, талановиті люди, врахування ключових положень цієї теорії при обгрунтуванні концепту смарт-спеціалізації, як нам видається, сприятиме зміцненню спроможності регіону.

Аналізуючи теоретичні підходи, які формують основу смарт-спеціалізації, а відтак і нової індустріальної політики, варто звернути увагу на концепт регіональної інноваційної системи (РІC), який набув широкого розголосу в дослідження еволюційної економіки. Сутність якого зводиться до того, що інноваційний розвиток регіону та економічне зростання стимулюються процесами взаємодії між сусідніми представниками бізнесу та установами, які генерують і поширюють знання (науководослідні організації, університети, центри трансферту технологій і ін.) [13-15]. На думку авторів[16] слід розрізняти «тонку» і «товсту» РІС. «Тонкі» РІС не вирізняються надмірною кількістю закладів вищої освіти чи потужним сектором промисловості, а тому суттєво залежать від траєкторії розвитку. Натомість, «товсті» PIC, як правило, розташовані на урбанізованих територіях, включають заклади вищої освіти, наукові установи, розвинутий сектор промисловості. Такі РІC практично не залежать від траєкторії розвитку, оскільки самі можуть генерувати її оновлення чи створювати нову (траєкторію).

Інакше кажучи, для того щоб досягнути радикальної зміни напряму розвитку території (чи появу нових галузей промисловості, які зможуть забезпечити конкурентні переваги) необхідним $є$ існування таких складових: наявність висококваліфікованих кадрів, «товсті» РІС і потужний внутрішній потенціал.

Впродовж останніх років посилення впливу інформаційних чинників (як то інформація чи знання) на соціально-економічний розвиток регіонів $\epsilon$ настільки помітним, що в науковому середовищі активно популяризується думка про те, що саме ці фактори зумовлюють інтелектуалізацію економіки. I це не дивно, адже сучасні інформаційні технології змінюють не тільки життя людей, методи і форми їх освіти, спосіб виробництва тощо, але і вагомо впливають на соціально-економічну структуру суспільства загалом. Розвиток технологій обумовлює виникнення різних ефектів та нагромадження знання. Саме такі ідеї розвитку узагальнено в концепції інформаційного cycniльства. До слова, недарма ООН включила в Цілі сталого розвитку на 2016-2030 р. p. створення стійкої інфраструктури, сприяння всеохоплюючій і сталій індустріалізації та інноваціям [17].

Зазначимо, що в науковій літературі дана концепція розглядається як похідна теорії постіндустріального суспільства (3. Бжезинського, Д. Белла і ін. ) та своєю «появою» завдячує роботам відомого дослідника Ф. Махлупи, який у 1933 році почав вивчати вплив патентів на наукові дослідження. На початку 60-х років минулого століття у своїй знаменитій праці «Виробництво й розподіл знань у Сполучених Штатах» автор увів поняття «індустрія знань», до якої він відніс п’ять секторів інформаційної діяльності в суспільстві: освіту, наукові дослідження й розробки, засоби масової інформації, інформаційні технології та інформаційні послуги [18]. Однак найбільшого визнання концепція інформаційного суспільства набула в період стрімкого поширення технологічних досягнень в країнах (70-80-ті роки мин. століття ), які активно освоювали нову інформацію і знання. 3 часом більшість прихильників даної теорії почали зміщувати акценти 3 домінуючої ролі інформації в сторону знань. Знаменита трилогія американського соціолога Е. Тоффлера [19-21] розкриває розуміння інформаційного суспільства 3 позиції нового етапу суспільного розвитку. Зміни в соціально-економічних системах, на думку автора, відбуваються внаслідок настання інформаційної епохи. Причому, зміни в технологічній та інформаційній сферах настільки переплелись, що призвели до принципового оновлення способу виробництва, яке поступово відходить традиційного. 
До характерних рис інформаційного суспільства відносять: збільшення ролі інформації і знань в житті суспільства; зростання кількості людей, зайнятих інформаційними технологіями, комунікаціями $\mathrm{i}$ виробництвом інформаційних продуктів і послуг, зростання їх частки у валовому внутрішньому продукті; зростання інформатизації та ролі інформаційних технологій в суспільних та господарських відносинах; створення глобального інформаційного простору, який забезпечує ефективну інформаційну взаємодію людей їх доступ до світових інформаційних ресурсів і задоволення їхніх потреб щодо інформаційних продуктів і послуг [22].

Видається, що ідеї теорії інформаційного суспільства можуть лягати в канву формування стратегічних пріоритетів соціально-економічного поступу як країни загалом, так і регіонів зокрема.

Розкриваючи теоретичні основи концепту смарт-спеціалізації, доречно звернути увагу на фундаментальні ідеї теорії клубів Дж. М. Б’юкенена, в літературі - «клубної економіки» [23], суть яких зводиться до того, що індивідууму легше задовольняти свої соціальні та економічні потреби в групі, аніж індивідуально. Створювати клуби доцільно у випадку більшої вигоди від колективного споживання блага на особу, аніж би це благо споживалося індивідуально. Чинниками колективних дій $є$ наявність загальної мотивації для різних включених у діяльність учасників, що дозволяє досягати надіндивідуальних цілей; наявність єдиного кінцевого результату, загального для учасників спільної діяльності; єдине просторово-часове функціонування учасників. Останній чинник - це одна 3 елементарних, але найбільш необхідних умов здійснення спільної діяльності, яка може бути реалізована за допомогою організації цифрових платформ [24]. Основні принципи цієї теорії стануть в нагоді при обгрунтуванні механізмів фінансування інноваційних проєктів.

Зважаючи на те, що участь зацікавлених сторін та співпраця між інституціями $€$ ключовими імперативами смарт-спеціалізації, а відтак і економічного розвитку регіонів, при дослідженні iї теоретичних засад, доречно опиратися на інституційну економіку, вагому нішу в дослідженнях якої посідають положення теорії колективних diй. Основоположником даної теорії є М. Олсон. У своїй знаменитій праці «Логіка колективної дії: суспільні блага і теорія груп» [25] автор відстоював ідею про те, що «лише окремий i «вибірковий» мотив стимулюватиме раціонального індивіда в латентній групі діяти в спосіб, запропонований групою» [25]. Запропонував розрізняти великі і малі групи, які можуть діяти заради досягнення спільної мети, причому будь яка група (організація), незалежно від величини, діятиме 3 метою задоволення колективного блага, яке буде вигідне усім членам групи. По-суті, це і є основною причиною виникнення групи. Інший важливий посил теорії - групи утворюються i працюють заради досягнення спільної мети тільки тоді, коли ії учасники будуть належним чином мотивовані.

Висновки, зроблені М. Олсоном дають змогу зрозуміти специфіку та мотиви внутрігрупових інтересів, що, своєю чергою, $є$ вельми корисним досвідом при обговоренні майбутньої стратегії, адже в процесі стратегування дуже важливо щоб групи учасників, задіяні до обговорення, були збалансовані, мінімум лобіювання інтересів зацікавлених сторін, ну і що не менш важливо - ініціатива відповідно до компетентностей, а не «власних амбіцій», але з урахуванням потенційних вигод.

Зважаючи на новітні тренди економічного зростання регіонів, неважко помітити, що драйвером економіки стають глобальні канали зв'язку, новітні технології та інформація. Ми є свідками того, як колективні дії поступово трансформуються в масове співробітництво. Знання, інформація, комунікаційні навики тощо самоорганізуються та трансформуються в потужну колективну силу, що діє узгоджено, мотивовано, керованою при допомозі чатів, мережевих партнерів тощо. Модель функціонування 
економіки нового покоління, що базується на інформації отримала широке визнання та іменується як вікіноміка. Своєю появою цей концепт завдячує американцям Дон Тапскотту і Ентоні Д. Уільямсу, які в своїй книзі «Викиномика. Как массовое сотрудничество изменяет все» [26] детально обгрунтовують суть нової моделі економічного зростання, в основі якої - феномен самоорганізації та нові форми взаємодії і співпраці суб'єктів (груп).

Головний посил авторів - максимальна відкритість перед суспільством та доступність інформації про діяльність бізнесу, інакше така діяльність залишиться поза соціумом. В основі вікіноміки - пірінгове виробництво - спосіб виробництва товарів і послуг, що базується на самоорганізації груп, члени яких, базуючись на добровільних засадах, об'єднуються для досягнення певних цілей [26]. Серед ключових принципів вікіекономіки - відкритість і спільне використання та функціонування у всьому світі.

На наш погляд, ідеї даної моделі економічного зростання набувають особливої актуальності в теперішніх умовах, позаяк розбудова взаємозв'язків між стейкхолдерами, розбудова і посилення багатостороннього партнерства, комунікації із зовнішніми мережами, формування і просування унікальності регіону тощо - це все важливі домінанти, синергія яких гарантуватиме підприємницьке відкриття, конкурентну перевагу регіону.

Висновки. Відмічаючи підвищений науково-практичний інтерес до смартспеціалізації, та враховуючи проведений огляд теоретичних концепцій, можемо стверджувати про незавершеність науково обгрунтованого теоретичного базису смартспеціалізації. Проаналізований ідейний арсенал теорій та концепцій, на яких слід вибудовувати теоретико-методологічне підгрунтя смарт-спеціалізацій далеко не $\epsilon$ вичерпним, водночас виправдовує доцільність їх врахування.

Разом $з$ тим, ведучи мову про безальтернативність формування вітчизняної політики регіонального розвитку на засадах смарт-спеціалізації, важливо чітко розуміти, що спрямованість іiі передбачає запровадження нових методів управління через тісну співпрацю між національними та регіональними органами влади, що відповідають за розроблення та впровадження регіональної політики на засадах смартспеціалізації, а також зацікавлених сторін. Водночас, як нам видається, смартспеціалізація не передбачає революційних перетворень в державній регіональній політиці. Її місія - вдосконалити існуючі методи стимулювання економічного розвитку через зростання конкуренції та поширення інновацій. Політика регіонального розвитку, що базується на інноваціях несе в собі великий потенціал до інтеграції регіональних економік у європейські ланцюги створення доданої вартості.

1. Foray D., David P., Hall B. Smart specialization: from academic idea to political instrument, the surprising career of a concept and the difficulties involved in its implementation. MTEI Working Paper. Lausanne, $\quad$ Switzerland, $16 . \quad 2011 . \quad$ URL: https://pdfs.semanticscholar.org/29ad/6773ef30f362d7d3937c483003d974bc91c5.pdf (дата звернення: 15.06.2021)

2. Белявцева В. В., Хрипунова Д. М. Ключові виклики реалізації стратегії смарт-спеціалізацій в Україні. Розвиток підприємниџтва в Украӥні: безпека здійснення господарської діяльності: матеріали круглого столу. URL: http://ndipzir.org.ua/conference/2018/12/14/Beliavtseva_ Khrypunova.pdf (дата звернення: 11.06.2021)

3. Амоша О., Лях О., Солдак М., Череватський Д. Інституційні детермінанти впровадження концепції смарт-спеціалізації приклад старопромислових шахтарських регіонів України. Журнал європейської економіки. Липень-вересень 2018. Т. 17. №3(66). С. 310-344.

4. Косенкова Т. В. Перспективи розвитку SMART-спеціалізації у Харківській області. Соціальна економіка. 2017. Вип. 53 (1). С. 76-80.

5. Возняк Г. В. Теоретико-методологічні аспекти формування моделі смарт-спеціалізації регіонів України. Регіональна економіка. № 2. 2021. С. 27-36. DOI: https://doi.org/10.36818/1562-0905-20212-3. 
6. Чикаренко I. А., Маматова Т. В. «Розумна спеціалізація» як цільовий орієнтир стратегічного розвитку територіальних громад. Strategic Management: Global Trends and National Peculiarities. Collective monograph. Poland: Publishing House «Baltija Publishing», 2019. C. 406-420.

7. Romer P. M. Endogenous Technological Change. Journal of Political Economy. 1990. Vol. 98 (5). P. 71.

8. Возняк Г.В. Фінансова децентралізація та стале ендогенне зростання регіонів: формалізація напрямів впливу. Світ фінансів. 2019. №2(59). С. 49-59.

9. Romer P. M. Growth based on increasing returns due to specialization. American Economic Review. 1987, May. Vol. 77(2). P. 145.

10. Райтнер Е. С. Як багаті країни стали багатими... I чому бідні країни залишились бідними. Саміткнига. 2019. 416 c.

11. Флоріда Р. Homo creatives. Як новий клас завойовує світ. Наш формат. 2018. 432 с.

12. Флорида Р. Креативный класс. Люди которые меняют будущее. Манн, Иванов и Фербер, 2015. $384 \mathrm{c}$.

13. Braczyk H.-J., Cooke P., Heidenreich M. Regional Innovation Systems: The Role of Governances in a Globalized World, $2^{\text {nd }}$ Ed. London: UCL Press, 1998. 442 p.

14. Asheim B. T., Coenen L. Knowledge bases and regional innovation systems: Comparing Nordic clusters. Research policy. 2005. No 8 (34). P. 1173-1190.

15. Isaksen A., Martin R., Trippl M. New avenues for regional innovation systems and policy. New avenues for regional innovation systems - Theoretical advances, empirical cases and policy lessons. Cham: Springer, 2018. P. 1-19.

16. Isaksen A., Trippl M. Path development in different regional innovation systems: A conceptual analysis. Innovation Drivers and Regional Innovation Strategies. New York, London: Routledge, 2016. P. 78-80.

17. Цілі сталого розвитку 2016-2030. 2016. URL: http://www.un.org.ua/ua/tsili-rozvytkutysiacholittia/tsili-staloho-rozvytku (дата звернення: 07.07.2021)

18. Махлуп Ф. Производство и распространение знаний в США. М.: Прогресс, 1966. 159 с.

19. Тоффлер Э. Шок будущего / пер. с англ. М.: ООО «Издательство АСТ», 2003. 557 с.

20. Тоффлер Э. Третья волна / пер. с англ. М.: ООО «Издательство АСТ», 2004. 781 с.

21. Тоффлер Э. Метаморфозы власти / пер. с англ. М.: ООО «Издательство АСТ», 2002. 669 с.

22. Степаненко В. П. Інформаційне суспільство. Енциклопедія Сучасної Украӥни: електронна версія [веб-сайт] / гол. редкол.: І. М. Дзюба, А. І. Жуковський, М. Г. Железняк та ін.; НАН України, НТШ. Київ: Інститут енциклопедичних досліджень НАН України, 2006. URL: https://esu.com.ua/search_articles.php?id=12462 (дата звернення 17.07.2021)

23. Buchanan J. M. An Economic Theory of Clubs. Economica. Vol. 32. No. 125 (Feb., 1965). P. 1-14.

24. Циркулярна смарт-спеціалізація старопромислових иахтарських регіонів України: монографія / Д. Ю. Череватський, М. О. Солдак, О. В. Лях, Ю. С. Залознова та ін.; заг. ред.: О. І. Амоша; Ін-т економіки пром-сті НАН України. Київ, 2020. С. 158-159.

25. Олсон М. Логіка колективної дї: суспільні блага і теорія груп. Пер. з анг. Київ: Лібра. 2004. 272 с.

26. Тапскотт Д., Уильямс Е. Викиномика. Как массовое сотрудничество изменяет все. М.: Best Business Books, 2009. 392 c.

\section{References}

1. Foray, D., David, P., and B. Hall. Smart specialization: from academic idea to political instrument, the surprising career of a concept and the difficulties involved in its implementation. MTEI Working Paper, no.16, 2011, pdfs.semanticscholar.org/29ad/6773ef30f362d7d3937c483003d974bc91c5.pdf. Accessed 15 Jun. 2021

2. Belyavtseva, V. V., and D. M. Khrypunova. "Key challenges of implementing the strategy of smart specializations in Ukraine." Entrepreneurship development in Ukraine: security of economic activity: Materials of the round table, 14 Dec 2018, ndipzir.org.ua/conference/2018/12/14/Beliavtseva_ Khrypunova.pdf. Accessed 11 Jun. 2021

3. Amosha, O., Lyakh, O., Soldak, M., and D.Cherevatskyy. "Institutional determinants of introduction of the concept of smart specialization are an example of old industrial mining regions of Ukraine.” Journal of European Economy, no. 3(66), 2018, pp. 310-344.

4. Kosenkova, T. V. "Prospects for the development of SMART-specialization in the Kharkiv region." Social economy, vol. 53 (1), 2017, pp. 76-80.

5. Voznyak, H. V. "Theoretical and methodological aspects of forming a model of smart specialization of the regions of Ukraine.” Regional economy, no.2, 2021, pp. 27-36, doi.org/10.36818/1562-0905-2021-23.

6. Chykarenko, I. A., and T. V. Mamatova "Smart specialization as a target of strategic development of territorial communities.” Strategic Management: Global Trends and National Peculiarities. Collective monograph. Baltija Publishing, 2019, pp. 406-420.

7. Romer, P. M. “Endogenous Technological Change.” Journal of Political Economy, vol. 98(5), 1990,p.71. 
Актуальні проблеми розвитку економіки регіону. Вип 17. T.1

8. Voznyak, H. V. "Financial decentralization and sustainable endogenous growth of regions: formalization of areas of influence.” The world of finance, no.2(59), 2019, pp. 49-59.

9. Romer, P. M. "Growth based on increasing returns due to specialization." American Economic Review, vol. 77(2), 1987, p. 145.

10. Raytner, E. S. How rich countries became rich... And why poor countries remained poor. Summit book,2019.

11. Florida, R. Homo creatives. How a new class is conquering the world. Our format, 2018.

12. Florida, R. Creative class. People who change the future. Mann, Ivanov and Ferber, 2015.

13. Braczyk, H.-J., Cooke, P., and M. Heidenreich. Regional Innovation Systems: The Role of Governances in a Globalized World, 2nd ed. London, UCL Press, 1998.

14. Asheim, B. T., and L. Coenen. "Knowledge bases and regional innovation systems: Comparing Nordic clusters.” Research policy, vol. 8 (34), 2005, pp. 1173-1190.

15. Isaksen, A., Martin, R., and M. Trippl. "New avenues for regional innovation systems and policy." New avenues for regional innovation systems - Theoretical advances, empirical cases and policy lessons. Cham, Springer, 2018, pp. 1-19.

16. Isaksen, A., and M.Trippl. "Path development in different regional innovation systems: A conceptual analysis.” Innovation Drivers and Regional Innovation Strategies. New York, London, Routledge, 2016, pp. 78-80.

17. United Nations. Sustainable Development Goals 2016-2030, www.un.org.ua/ua/tsili-rozvytkutysiacholittia/tsili-staloho-rozvytku. 2016. Accessed 11 Jul. 2021

18. Machlup, F. Production and dissemination of knowledge in the United States. Moscow, Progress, 1966.

19. Toffler, E. Shock of the future. Trans. from English. Moscow, AST Publishing House, 2003.

20. Toffler, E. The third wave. Trans. from English. Moscow, AST Publishing House, 2004.

21. Toffler, E. Metamorphoses of power. Moscow, AST Publishing House, 2002.

22. Stepanenko, V. P. "Information society." Encyclopedia of Modern Ukraine: electronic version. Kyiv, Institute of Encyclopedic Research of the National Academy of Sciences of Ukraine, 2006, esu.com.ua/search_articles.php?id=12462. Accessed 05 Jul. 2021.

23. Buchanan, J. M. “An Economic Theory of Clubs.” Economica, Feb 1965, 32 (125), pp. 1-14.

24. Amosha, O. I. (Ed.), Cherevatskyy, D. Yu., et al. Circular smart specialization of old industrial mining regions of Ukraine. Kyiv, Institute of Industrial Economics, National Academy of Sciences of Ukraine, 2020, pp. 158-159.

25. Olson, M. The logic of collective action: public goods and group theory. Kyiv, Libra, 2004.

26. Tapscott, D., and Williams, E. Wikinomics. How Mass Collaboration Changes Everything. Moscow, Best Business Books, 2009.

УДК 352.071:005.21(477)

doi: 10.15330/apred.1.17.162-173

\section{СУТНІСТЬ СТРАТЕГІЇ СОЦАЛЬНО-ЕКОНОМІЧНОГО РОЗВИТКУ ОТГ В КОНТЕКСТІ ЗМІНИ ПІДХОДІВ ДО РЕГІОНАЛЬНОГО РОЗВИТКУ В УКРАЇ̈I}

1 ДВНЗ «Прикарпатський національний університет імені

Василя Стефаника»,

Міністерство освіти і науки України,

кафедра теоретичної і прикладної економіки,

вул. Шевченка, 57, м. Івано-Франківськ,

76018, Україна,

тел.: 0990630085,

e-mail: styartsave959@gmail.com,

ORCID: 0000-0003-4802-037X 